DIW BERLIN

Discussion

Papers
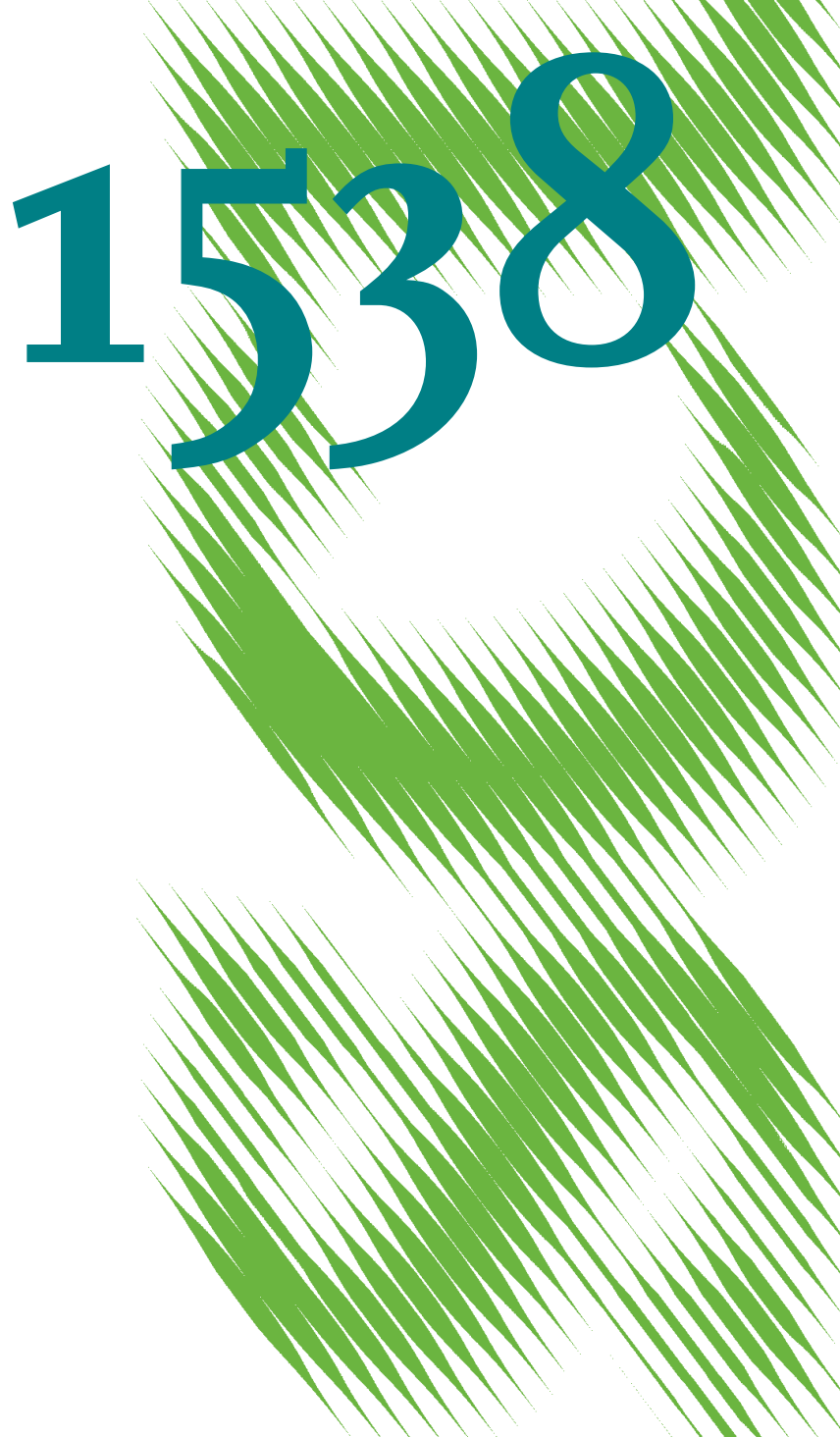

Local and Spatial Cointegration in the Wage Curve - A Spatial Panel Analysis for German Regions 
Opinions expressed in this paper are those of the author(s) and do not necessarily reflect views of the institute.

IMPRESSUM

(C) DIW Berlin, 2015

DIW Berlin

German Institute for Economic Research

Mohrenstr. 58

10117 Berlin

Tel. +49 (30) $89789-0$

Fax +49 (30) $89789-200$

http://www.diw.de

ISSN electronic edition 1619-4535

Papers can be downloaded free of charge from the DIW Berlin website:

http://www.diw.de/discussionpapers

Discussion Papers of DIW Berlin are indexed in RePEc and SSRN:

http://ideas.repec.org/s/diw/diwwpp.html

http://www.ssrn.com/link/DIW-Berlin-German-Inst-Econ-Res.html 


\title{
Local and Spatial Cointegration in the Wage Curve - A Spatial Panel Analysis for German Regions
}

\author{
Reinhold Kosfeld \\ University of Kassel, Nora-Platiel-Str. 4, 34127 Kassel, Germany. \\ E-mail: rkosfeld@uni-kassel.de \\ Christian Dreger
German Institute of Economic Research (DIW Berlin), Mohrenstr. 58, D-10117 Berlin, Germany and Europa-Universität Viadrina, 15230 Frankfurt (Oder), Germany. \\ E-Mail: cdreger@diw.de
}

\begin{abstract}
The wage curve introduced by Blanchflower and Oswald $(1990,1994)$ postulates a negative correlation between wages and unemployment. Empirical results focus on particular theoretical channels establishing the relationship. Panel models mostly draw on unionized bargaining or the efficiency wage hypothesis. Spatial econometric approaches can be rationalized by monopsonistic competition. However, the approaches either ignore the issue of nonstationarity or treat the data as if it were nonspatial. In this paper, we adopt a global cointegration approach recently proposed by Bienstock and Felsenstein (2010) to account for nonstationarity of regional data. By specifying a spatial error correction model (SpECM), equilibrium adjustments are considered in both space and time. Applying the methodology for West German labour markets, we find strong evidence for the existence of a long-run wage curve with spatial effects.
\end{abstract}

Keywords: wage curve, regional labour markets, spatial panel models, global cointegration analysis

JEL classification: J30, J60, C33, R15 


\section{Introduction}

Labour market institutions are seen as one of the principal factors crucial for the adjustment of labour markets to external shocks (cf. Blanchard and Wolfers 2000). Many countries have implemented reforms to reduce rigidities of their labour markets. In Germany, a package of reforms called Agenda 2003 was launched with the aim to increase the flexibility of the labour market. Commonly empirical studies understand labour market flexibility as wage flexibility, i.e. the response of wages to changing labour market conditions (cf. Bande, Fernández and Montuenga 2012). Flexibility of wages is of particular of importance for the competitiveness of firms in absence of other channels to mitigate external shocks and their impact on employment (Gertler 2010).

Blanchflower and Oswald (1990, 1994, 1995, 2005) provide empirical evidence on the existence of a negative relationship between the wages of workers and regional unemployment. The negative wage-unemployment nexus is observed for a large number of countries and seems to hold independently of the observation period. Blanchflower and Oswald (1994) give rationalizations for a downward-sloping wage curve from non-competitive market behaviour. In particular, they draw on the efficiency wage model and the bargaining model (see also Card 1995). However, follow-up studies did not validate a uniform unemployment elasticity of pay the wage of about -0.1 across countries. In a meta-study, Nijkamp and Poot (2003) showed considerable heterogeneity among estimated wage curve elasticities with a mean of 0.07 after correcting for publication bias.

The wage curve is typically estimated as a Mincer-type earnings function (Heckman, Lochner and Todd, 2003) with an enriched set of control variables for individual or regional characteristics. While the use of the panel environment is meanwhile standard, present wage curve studies differ with respect to the disaggregation level, econometric modelling, the choice of estimation techniques, the set of control variables and time periods. Many studies adopt the view of a causality running from the extent of joblessness to the wage level. However, when feedback effects are at work, controlling for simultaneity may become crucial. Mostly wage curve analysis 
treats local labour markets as isolated economies in spite of the presence of commuter flows between the place of residence and job location. If working conditions in a neighbouring region are favourable relative to costs of commuting, workplaces outside the home region are attractive for employees. The inclusion of spatial spillovers in the wage curve is grounded in the theory of monopsonistic competition (Longhi, Nijkamp and Poot 2006; Fingleton and Palombi 2013). The application of a spatial approach to wage curve estimation is particularly found in German studies (Büttner 1999; Longhi, Nijkamp and Poot 2006; Elhorst, Blien and Wolf 2007; Baltagi, Wolf and Blien 2012; Fingleton and Palombi 2013).

The discovery of the regional wage curve challenged the foundation of the macroeconomic Phillips curve. Using dynamic panels, Pannenberg and Schwarze (2000) provide evidence on a West German wage curve with partial equilibrium adjustment. This finding was confirmed by Ammermüller et al. (2010) and Baltagi, Blien and Wolf (2012) on the basis of different panel approaches. While Pannenberg and Schwarze (2000) and Ammermüller et al. (2010) do not account for spatial interactions, Baltagi, Blien and Wolf (2012) adopt a spatial modelling framework. In spite of the different approaches, the estimated wage curve elasticities are distinctly lower than stated in Blanchflower and Oswald's $(1990,1994)$ empirical law.

In case of a temporary phenomenon, the wage curve is not contradictory to the compensating differentials hypothesis (cf. Harris-Todaro 1970). Here, the expected utility for all regions converges to the same level in the long-run. According to the hypothesis, a compensation in wages for workers living in disadvantaged, highunemployment areas is expected. Using a efficiency wage model with non-pecuniary benefits Blanchflower and Oswald (1994b, pp. 64, 2005) show how a negatively sloped wage curve is obtained in long-run equilibrium. In high unemployment regions workers are compensated for low wages by intrinsic regional amenities. This notion considers the wage curve not as a temporary phenomenon but as an equilibrium relationship rationalized by non-competetive market theory.

Blanchflower and Oswald (1995) point to the potential of error-correction models (ECM) "to distinguish between dynamics and the properties of long-run equilibrium" in the wage-unemployment nexus. This suggestion has been seized by Ammermüller et 
al. (2010) who specify panel error-correction models (PECM) of the wage curve for Germany and Italy. While the PECM captured equilibrium adjustment within regions, error correction between areas is neglected. On the other hand, Baltagi, Blien and Wolf (2012) adopt a dynamic spatial panel data approach without addressing the issue of nonstationarity (Baltagi, Blien and Wolf 2012). An integration of spatial econometrics and panel cointegration in empirical modelling the wage-unemployment relationship is still lacking.

In this paper we adopt a global cointegration approach (Beenstock and Felsenstein 2010) to study the West German wage curve. While the need of a proper handling of nonstationary variables is by now well understood in standard econometric panel analysis (Choi 2012), aspects of spurious regression are usually ignored in spatial analysis. Global cointegration takes account of local and spatial adjustment processes between nonstationary variables. The modelling framework consists of a panel cointegrating relationship and a spatial error correction model (SpECM). The SpECM aims at merging the long- and short-run perspective in identifying comovements of wages and unemployment within and between the cross-sections. The merit of the approach lies in the potential of revealing the consequences of spatial effects for the time series behaviour of the variables (cf. Mitze and Özyurt 2014).

The results show that regional spillovers play a crucial role in establishing the equilibrium locus in West German labour markets. While standard cointegration analysis only offers weak evidence for a stable long-run wage-curve, a highly significant cointegrating relationship is obtained when spillovers from nearby regions are included. High unemployment spillovers corroborate the theory of monopsonistic competition. The existence of a regional Phillips curve is clearly rejected.

The paper is structured as follows. Section 2 reviews the theoretical foundations of the concept of the wage curve. Section 3 deals with methodical issues of the global cointegration approach. In section 4, variables and data are described. Empirical findings from panel analysis on the long-run relationship as well as local and spatial adjustment between regional wages and unemployment are discussed in section 5 . Section 6 summarizes the main results and offers some conclusions. 


\section{The concept of the wage curve}

The wage curve implies a negative relationship between the wage rate of workers and the regional unemployment rate. According to Mincer's earnings function, individual characteristics such as education and professional experience are seen as the main determinants of wages (Heckman, Lochner and Todd 2003). Including the unemployment rate in the relationship usually shifts the interest of the dependence of wages on regional labour market conditions. The term wage function is used when the other variables serve as controls. Blanchflower and Oswald (1994, 1995, 2005) presented evidence for the negative link between wages and unemployment that does not to disappear when controlled by an enriched set of individual characteristics. Nonlinearites in the relationship are also present for different reasons such as minimum wages or a wage floor. In its general form the standard wage curve is given by

(1) $w_{\text {irt }}=g\left[f\left(u_{r t}\right), X_{\text {irt }}, X_{2 i r t}, \ldots, X_{\text {mirt }}\right]$

with $\frac{\partial w_{\text {irt }}}{\partial u_{\mathrm{rt}}}<0$ and $\frac{\partial w_{\text {irt }}<}{\partial \mathrm{X}_{\text {jirt }}>}=0, j=1,2, \ldots, \mathrm{m}$,

where $w_{\text {irt }}$ is the wage rate observed for worker $i$ in region $r$ and time $t, u_{r t}$ the regional unemployment rate and $X_{1 i r t}, X_{2 i t}, \ldots, X_{\text {mirt }}$ denote the individual characteristics.

Competitive models of the labour market are shown to fall short in explaining the negative association between individual wages and regional unemployment (Blanchflower and Oswald 1995; Card 1995). In the neoclassical model involuntary unemployment - defined as the gap between labour supply and demand - will increase with rising wages. This would lead to a positive link between unemployment and wages. Interpreting the wage curve as a standard labour supply curve fails, because people not offering work at a given wage rate are not involuntarily unemployed. Moreover, the unemployment rate usually outperforms supply side measures like the participation or the employment rate in the relationship (Blanchflower and Oswald 1995; Card 1995).

On these grounds, the wage curve is based on non-competitive market structures. Specifically, a negative linkage between employment and pay could be explained by the labour contract and union bargaining models. The labour contract model 
assumes that firms and workers consider regional amenities in maximizing their joint utility. If unemployment benefits are constant across regions, areas with high amenities will offer contracts with lower wages that are associated with higher unemployment. Conversely, high wages and low unemployment predominate in regions with lower amenities.

Although pacts of employment and competitiveness relieved wage agreements at the firm level in Germany (Seifert and Massa-Wirth 2005), collective bargaining is still dominant (Fitzenberger, Kohn and Lembcke 2013). Hence, the union bargaining model could be another candidate to explain the wage curve. Because of job opportunities are scarce, unions' bargaining power decreases in slack labour markets. By contrast, their power increases with better employment prospects. Thus, negotiated wages will negatively depend on the unemployment level. However, in Germany, collective agreements do not differ across the regions, but only at the industry level (Fitzenberger, Kohn and Lembcke 2013).

The efficiency wage hypothesis provides an explanation of wages that is not linked to a particular institutional setting. According to the model proposed by Shapiro and Stiglitz (1984), employers offer wage premiums to promote workers' efforts and avoid shirking. In view of high costs of monitoring the workers' productivity, particularly in large firms, this strategy does not run contrary to profit maximization. The higher the unemployment rate, the more difficult workers will find a new job in case of a dismissal. Against this backdrop, firms can afford to offer lower wage premiums in slack labour markets. Therefore, a negative link between regional unemployment and wage should be expected. With the labour turnover model (Campbell and Orszag 1998) as a special variant of the efficiency wage hypothesis, the wage curve is drawn on fixed costs for recruiting and training. Firms set wages in considering fixed costs of providing training for newly hired workers and wages paid to those already employed. Due to high recruitment and training costs, employers will pay higher wages to keep current employees and discourage them to quit. Wage premiums will be higher in tight labour markets than in periods of economic downturns, where it is less likely that workers quit and find new jobs. Although the efficiency wage hypothesis is non-spatial, it can be adopted within a system of interacting regions (Longhi, Nijkamp and Poot 2006). 
The theory of monopsonistic competition introduces the regional dimension to the labour turnover cost approach (Longhi, Nijkamp and Poot 2006; Fingleton and Palombi 2013). Considering commuting flows across regions, local labour markets cannot be longer treated as isolated entities. In the presence of spatial interactions among neighboring territories, competition for workers takes place within larger labour market areas. Not only economic conditions in the local labour market but as well as in neighbouring labour markets will affect local wages. In recruiting and retaining workers, competition on wages takes place between interacting nearby regions. Thus, local wages $w_{\mathrm{rt}}$ are determined by own and neighbouring regions unemployment, $u_{r t}$ and $S L\left(u_{r t}\right)$, and wages in adjacent regions, $S L\left(w_{r t}\right)$, after controlling for regional characteristics $X_{j r t}$ and $S L\left(X_{j r t}\right), j=1,2, \ldots, m$ :

(2) $w_{\text {irt }}=g\left\{S L\left[h\left(w_{r t}\right)\right], f\left(u_{r t}\right), S L\left[f\left(u_{r t}\right)\right], X_{1 r t}, \ldots, X_{m r t}, S L\left(X_{1 r t}\right) \ldots, S L\left(X_{m r t}\right)\right\}$

with $\frac{\partial w_{r t}}{\partial S L\left(w_{r t}\right)}>0, \frac{\partial w_{r t}}{\partial u_{r t}}<0, \frac{\partial w_{r t}}{\partial S L\left(u_{r t}\right)}<0, \frac{\partial w_{r t}}{\partial X_{j r t}}=0, \frac{\partial w_{r t}}{\partial S L\left(X_{j r t}\right)}=0, j=1,2, \ldots, m$.

Both spillover effects, $S L\left(w_{r t}\right)$ and $S L\left(u_{r t}\right)$, tend to weaken the responsiveness of the wage rate to changes in the regional unemployment rate. Due to lesser mobility and recruiting costs, the theory of monopsonistic competition predicts a lower local unemployment elasticity of pay in agglomerated regions. Thus, agglomeration effects may be reflected in the wage curve elasticity, but also directly affect the level of pay.

\section{Methodical issues}

The variables in the original wage curves (1) are measured for different types of statistical units. While the wage rate $w_{\text {irt }}$ refers to individuals, the unemployment rate $\mathrm{u}_{\mathrm{rt}}$ relates to regions. The regression will lead to a bias if workers in the same regional labour market share some common components of variance reflected in explanatory variables and disturbances. Hence, the errors are expected to be positively autocorrelated across individuals in the same labour market so that the standard error of the regression coefficients will be underestimated (Moulton 1990).

The common group effect is addressed here by averaging individual-specific variables over all workers in a particular labour market. Eventually, individual aggregation is required in the presence of spatial effects regardless of the estimation 
strategy used (cf. Baltagi, Blien and Wolf 2012). This leads to the general spatial wage curve in equation (2). In specifying the model, the log-log specification is most widespread functional form (Blanchflower and Oswald 1994, 2005).

Wage and unemployment spillovers, $S L\left[\log \left(\mathrm{w}_{\mathrm{r} t}\right)\right]$ and $\mathrm{SL}\left[\log \left(\mathrm{u}_{\mathrm{r} t}\right)\right]$, can be operationalized with the spatial weights matrix $\Omega^{\star}$. Its elements $\omega_{\mathrm{rs}}^{*}$ are defined by

$$
\omega_{\mathrm{rs}}^{\star}=\left\{\begin{array}{l}
1 \text { if regions } r \text { and } \mathrm{s} \text { share a common boundary (edge) } \\
0 \text { otherwise }
\end{array}\right.
$$

The spatial weights $\omega_{\mathrm{rs}}^{*}$ are zero for $\mathrm{r}=\mathrm{s}$. Using the row-standardized weights, $\omega_{\mathrm{rs}}=\omega_{\mathrm{rs}}^{*} / \sum_{\mathrm{h}=1}^{\mathrm{n}} \omega_{\mathrm{rh}}^{*}$ (Anselin and Bera 1998, p. 243), the spatial lags of the core variables read

$$
\mathrm{SL}\left(\log \left(w_{\mathrm{rt}}\right)\right)=\sum_{\mathrm{s}=1}^{\mathrm{n}} \omega_{\mathrm{rs}} \cdot \log \left(\mathrm{w}_{\mathrm{st}}\right) \text { and } \mathrm{SL}\left(\log \left(\left(\mathrm{u}_{\mathrm{rt}}\right)\right)=\sum_{\mathrm{s}=1}^{\mathrm{n}} \omega_{\mathrm{rs}} \cdot \log \left(\mathrm{u}_{\mathrm{st}}\right) .\right.
$$

They represent spillover variables captured by the log wage and unemployment rates in the neighbouring regions. After including the spatial lags of the control variables, $S L\left(X_{j r t}\right)=\sum_{S=1}^{n} \omega_{r s} X_{j s t}$, the pooled panel model of the wage curve takes the form

(3) $\log \left(w_{r t}\right)=\alpha+\lambda \cdot S L\left(\log \left(w_{r t}\right)\right)+\beta \cdot \log \left(u_{r t}\right)+\beta^{*} \cdot S L\left(\log \left(u_{s t}\right)\right)$

$$
+\sum_{j=1}^{m} \delta_{j} \cdot X_{j r t}+\sum_{j=1}^{m} \delta_{j}^{*} \cdot S L\left(X_{j r t}\right)+\varepsilon_{r t}
$$

where $\alpha$ is the intercept, $\lambda$ a spatial autoregressive parameter, $\beta$ and $\beta^{\star}$ regressions coefficients of own region's and neighbouring regions' unemployment rate and $\delta_{\mathrm{j}}$ and $\delta_{j}^{*}$ regression coefficients of regional characteristics. If the variables measure all systematic influences on regional wages, the disturbances $\varepsilon_{\mathrm{rt}}$ will be spatially and temporally uncorrelated.

Generally not all explanatory variables are observable. Unobservable explanatory variables can be introduced into the spatial wage curve (3) by fixed effects: 
(4) $\log \left(w_{r t}\right)=\alpha_{r}+\alpha_{\bullet t}+\lambda \cdot S L\left(\log \left(w_{r t}\right)\right)+\beta \cdot \log \left(u_{r t}\right)+\beta^{\star} \cdot S L\left(\log \left(u_{s t}\right)\right)$

$$
+\sum_{j=1}^{m} \delta_{j} \cdot X_{j r t}+\sum_{j=1}^{m} \delta_{j}^{*} \cdot S L\left(X_{j r t}\right)+\varepsilon_{r t} .
$$

The $\alpha_{r_{0}}, r=1,2, \ldots, n$, are regional fixed effects and the $\alpha_{\bullet t}, t=1,2, \ldots, T$, time fixed effects. According to equation (4), the wage curve is shaped as a spatial Durbin panel model (SDPM) with fixed effects (FE). The case $\beta^{\star}=0$ and $\delta_{j}^{*}=0$ for all $j$ typifies a spatial panel lag model and the case $\lambda=0$ into an SLX panel model. ${ }^{1}$ The nonspatial fixed effects (FE) panel model results for $\lambda=\beta^{\star}=0$ and $\delta_{j}^{\star}=0$ for all $\mathrm{j}$.

The view of the wage curve as a long-run equilibrium relationship has often been discussed. From this perspective, equation (4) displays a cointegrating relationship between wages, unemployment and regional characteristics. Blanchflower and Oswald $(1990,1995)$ substantiate the equilibrium long-run relationship between wage and regional unemployment by non-competitive labour market theories. Involuntary unemployment is shown to be compatible with a non-competitive equilibrium. Blanchflower and Oswald's findings of a negative unemployment elasticity of pay contrast the compensating differential approach (Harris-Todaro 1970; Topel 1986) of a positive link between wages and unemployment. According to this hypothesis, a negative wage-unemployment nexus can only be a temporary phenomenon.

Blanchflower and Oswald (1994) provide overwhelming evidence for a negative relationship between wages and regional unemployment for a wide variety of countries over long time periods. Their findings are qualitatively corroborated by the meta-study of Nijkamp and Poot (2005). By making allowance for the autoregressive nature of wages, Blanchflower and Oswald (2005) "view the data as being characterized by dynamic fluctuations around a long-run wage curve". In the case of nonstationary panel data, the econometric counterpart of the long-run equilibrium is a cointegrating relationship between the variables.

\footnotetext{
${ }^{1}$ SLX stands for spatial lag of independent variables (X variables). For a taxonomy of spatial panel data models s. Elhorst (2009).
} 
In order to be cointegrated, at least two variables must share the highest order of integration. Panel unit root tests usually assume cross-sectionally independently distributed time series of the panel units. This assumption is particularly violated in spatial panels. Pesaran (2007) augmented the IPS test by adopting a common factor model for capturing cross-sectional dependence. By additionally accounting for serial dependence in form of an $\mathrm{AR}(1)$ error process, the test equation reads

(5) $\Delta y_{r t}=a_{r}+b_{r} \cdot y_{r, t-1}+c_{r} \cdot \bar{y}_{t-1}+d_{r 0} \cdot \Delta \bar{y}_{t}+d_{r 1} \cdot \Delta \bar{y}_{t-1}+e_{r} \cdot \Delta y_{r, t-1}+u_{r t}$

for a variable y with an intercept and without a deterministic trend. In this approach, the common factor is proxied by the cross-section mean $\bar{y}_{t}$ and its lagged values. Already for moderate values of $n$ and $T$, the cross-sectionally augmented IPS test (CIPS test) has satisfactory size and power.

Panel cointegration tests differ in the way they treat cross-sectional dependence, heterogeneity and idiosyncratic components. Here we apply the two-step procedure of Holly, Pesaran and Yamagata (HPY, 2010) in testing for integration. The HPY test accounts for cross-sectional dependence by adopting a common factor approach. In the first step, the wage curve is estimated by excluding and including spatial effects. In the second step, the residuals of the potential long-run relationship (3) are tested for a unit root by the CIPS test. Thereby spatial heterogeneity is taken into account. A rejection of the unit root hypothesis gives evidence for a cointegrating relationship. By applying the HPY test to the non-spatial and spatial panel model, clues on the role of spatial effects in establishing a long-run wage curve are obtained.

While the regression coefficients of the non-spatial panel model exhibit the effects of a unit change of the explanatory variables $\log \left(u_{r}\right)$ and $x_{j r}, j=1,2, \ldots, m$, on the dependent variable $\log \left(w_{r}\right)$, this does not hold in the spatial setting due to the inclusion of the endogenous spatial lag variable. The reason for this is that the regression coefficients of the explanatory variables neglect feedback loops as components of the own-partial derivatives $\partial \log \left(w_{r}\right) / \partial \log \left(u_{r}\right)$ and $\partial \log \left(w_{r}\right) / \partial x_{j r}$. Feedback loops represent direct effects where, for instance, an observation $r$ affects another observation $s$, which in turn influences observation r. Indirect impacts are measured by the cross-partial derivatives $\partial \log \left(w_{r}\right) / \partial \log \left(u_{s}\right)$ and $\partial \log \left(w_{r}\right) / \partial x_{j s}, s \neq r$. As these also involve feedback loops, they usually differ from the regression coefficients of the spatial lag variables. 
In the spatial analysis of the wage curve, the effects of local and surrounding unemployment rates on the wage rate are in the focus of interest. With $\log \left(\mathbf{w}_{\mathrm{t}}\right)$ and $\log \left(\mathbf{u}_{\mathrm{t}}\right)$ as $\mathrm{n} \times 1$ vectors of the logarithmic wage and unemployment rates, respectively, $\Omega$ the nxn row-standardized spatial weights matrix and $I_{n}$ the $n \times n$ identitiy matrix, the nxn matrix of partial derivatives $\partial \log \left(\mathbf{w}_{\mathrm{r}}\right) / \partial \log \left(\mathbf{u}_{\mathrm{s}}\right)$ can be written as

(6) $\frac{\partial \log \left(\mathbf{w}_{t}\right)}{\partial \log \left(\mathbf{u}_{t}\right)}=\left(\mathbf{I}_{\mathrm{n}}-\lambda \cdot \mathbf{\Omega}\right)^{-1} \cdot\left(\beta \cdot \mathrm{I}_{\mathrm{n}}+\beta^{*} \cdot \mathbf{W}\right)$.

for the spatial Durbin model of the wage curve (4). While the diagonal elements of the matrix $\partial \log \left(\mathbf{w}_{\mathrm{t}}\right) / \partial \log \left(\mathbf{u}_{\mathrm{t}}\right)$ represent the direct effect, its off-diagonal elements capture the indirect effects of unemployment on wages. The latter are obtained by the sums of the columns or rows of the matrix $\partial \log \left(\mathbf{w}_{\mathrm{t}}\right) / \partial \log \left(\mathbf{u}_{\mathrm{t}}\right)$ omitting the respective diagonal element. The derivatives $\partial \log \left(w_{r}\right) / \partial \log \left(u_{r}\right)$ and $\partial \log \left(w_{r}\right) / \partial u_{s}, s \neq r$, can be interpreted as local and external unemployment elasticities of pay that generally differ from region to region. Only in the absence of spatial wage spillovers, direct and indirect wage curve elasticities coincide with the regression coefficients $\beta$ and $\beta^{*}$.

With the series expansion of the inverse $\left(I_{n}-\lambda \cdot \Omega\right)^{-1}$,

(7) $\left(I_{\mathrm{n}}-\lambda \cdot \mathbf{\Omega}\right)^{-1}=I_{\mathrm{n}}+\lambda \cdot \mathbf{\Omega}+\lambda^{2} \cdot \mathbf{\Omega}^{2}+\lambda^{3} \cdot \mathbf{\Omega}^{3}+\ldots$

spatially partitioned effects can be obtained. As regional labour markets are expected to include directly neighbouring areas, a differentiation between first-order and higher-order indirect effects is of main interest.

Because the wage derivatives with respect to unemployment depend on the spatial arrangement of areas, they vary from region to region. This also holds for the total impact of a change in the unemployment rate on the regional wage rate. LeSage and Pace (2009, p. 39) propose scalar measures to assess the average impact of explanatory variables on the dependent variable. According to this concept, the local elasticity of wage, $\gamma_{u, w}^{\text {dir }}$, is given by

(8) $\gamma_{\mathrm{u}, \mathrm{w}}^{\mathrm{dir}}=\mathrm{n}^{-1} \cdot\left[\operatorname{tr}\left(\mathbf{I}_{\mathrm{n}}-\lambda \cdot \mathbf{\Omega}\right)^{-1} \cdot\left(\beta \cdot \mathrm{I}_{\mathrm{n}}+\beta^{*} \cdot \mathbf{W}\right)\right]$.

The external elasticity of pay, $\gamma_{u, w}^{\text {ind }}$, is obtained from total wage curve elasticity,

(9) $\gamma_{\mathrm{u}, \mathrm{w}}^{\mathrm{tot}}=\mathrm{I}^{\prime} \cdot\left[\operatorname{tr}\left(\mathrm{I}_{\mathrm{n}}-\lambda \cdot \mathbf{\Omega}\right)^{-1} \cdot\left(\beta \cdot \mathrm{I}_{\mathrm{n}}+\beta * \mathbf{W}\right)\right] \cdot \mathbf{I}$ 
with $\mathbf{\imath}$ is an $n \times 1$ vector of ones, residually:

(10) $\gamma_{u, w}^{\text {ind }}=\gamma_{u, w}^{\text {tot }}-\gamma_{u, w}^{\text {dir }}$.

Recent studies on the wage-unemployment nexus discovered not only the relevance of spatial effects but also a central role of wage dynamics (Baltagi, Blien and Wolf 2009, 2012; García-Mainar and Montuenga-Gómez 2012; Ramos, Nicodemo and Sanroma 2015). Although Blanchflower and Oswald (1995) pointed to errorcorrection models as feasible devices to distinguish between dynamics and the properties of a long-run equilibrium, studies on the regional wage curve usually introduce dynamics by adding lagged wages and unemployment rates. Wage adjustment within an error correction model applied to the regional setting has been advocated by Ammermüller et al. (2012). This framework provides a flexible dynamic specification of regional wage curve, but neglects spatial effects. Adjustments to equilibrium wage levels within the regions are considered, but not between them.

Recently, Beenstock and Felsenstein (2010) extended the standard panel error correction model (PECM) by "spatializing" the adjustment to equilibrium. The errorcorrection mechanism is assumed to work not only within but also between the regions. While the effectiveness of local error correction is checked, as usual, by the coefficient of the lagged residuals $E_{r, t-1}$ from the equilibrium relationship (4), the presence of spatial correction is assessed by evaluating the coefficient of the lagged residuals of neigbouring regions $E_{\mathrm{r}, \mathrm{t}-1}^{*}$. The spatial error correction model (SpECM) captures additionally the effects of variations of the model variables and their spatial lags on changes in wages. By adopting a second-order autoregressive process, the dynamic counterpart of the cointegrating relationship (4) reads

$$
\begin{aligned}
& \text { (11) } \Delta\left(\log \left(\mathrm{w}_{\mathrm{rt}}\right)\right)=\alpha+\phi_{1} \cdot \Delta\left(\log \left(\mathrm{w}_{\mathrm{r}, \mathrm{t}-1}\right)\right)+\phi_{0}^{*} \cdot \Delta \mathrm{SL}\left(\log \left(\mathrm{w}_{\mathrm{rt}}\right)\right)+\phi_{1}^{*} \cdot \Delta S L\left(\log \left(\mathrm{w}_{\mathrm{r}, \mathrm{t}-\mathrm{l}}\right)\right) \\
& +\gamma_{0} \Delta\left(\log \left(\mathrm{u}_{\mathrm{rt}}\right)\right)+\gamma_{1} \Delta\left(\log \left(\mathrm{u}_{\mathrm{r}, \mathrm{t}-1}\right)\right)+\gamma_{0}^{*} \Delta \mathrm{SL}\left(\log \left(\mathrm{u}_{\mathrm{rt}}\right)\right)+\gamma_{1}^{*} \Delta \mathrm{SL}\left(\log \left(\mathrm{u}_{\mathrm{r}, \mathrm{t}-1}\right)\right)+\sum_{\mathrm{j}=1}^{m} \theta_{\mathrm{j} 0} \Delta \mathrm{X}_{\mathrm{jrt}} \\
& +\sum_{\mathrm{j}=1}^{m} \theta_{\mathrm{j} 1} \Delta \mathrm{X}_{\mathrm{jr}, \mathrm{t}-1}+\sum_{\mathrm{j}=1}^{m} \theta_{\mathrm{j} 0}^{*} \Delta \mathrm{SL}\left(\mathrm{X}_{\mathrm{jrt}}\right)+\sum_{\mathrm{j}=1}^{m} \theta_{\mathrm{j} 1}^{*} \Delta \mathrm{SL}\left(\mathrm{X}_{\mathrm{jr}, \mathrm{t}-1}\right)+\alpha \mathrm{EC}_{\mathrm{r}, \mathrm{t}-1}+\alpha^{*} \cdot \mathrm{EC}_{\mathrm{r}, \mathrm{t}-1}^{*}+v_{\mathrm{rt}} \cdot
\end{aligned}
$$

For local error correction to be effective, the adjustment coefficient $\alpha$ must take a negative sign. In this case, previous deviations from local equilibrium wages are 
gradually reduced in later periods. Spatial error correction relates to the adjustment across space. A positive sign of the error correction coefficient $\alpha^{*}$ indicates the effectiveness of an adjustment process between proximate regions. Both coefficient $\alpha$ and $\alpha^{\star}$ measure the speed of adjustment towards the long-run equilibrium. If both inequalities $-1 \leq \alpha<0$ and $0<\alpha^{*} \leq 1$ hold, the system is said to be globally cointegrated, as gradual adjustment takes place. ${ }^{2}$ The borderline case $\alpha=\alpha^{*}=1$ indicates full adjustment within one period. In the special case $\alpha=\alpha^{*}=0$, the spatial error correction model (SpECM) turns into a spatial vector autoregression as an adequate dynamic modelling framework for stationary variables. By combining the cointegrating relationship (4) with the SpECM (11) a dynamic spatial wage curve is obtained that is similarly structured to its standard representation.

\section{Data}

The wage-unemployment nexus is investigated for West German regions in the period from 1995 to 2010. The East-West divide in the levels of pay and unemployment is not the only reason for focusing on the old German Länder. The long-lasting adjustment process in the new Länder West German may obscure a negative relationship between the wage and unemployment rate. In particular the launch of large scale active labor market policies (ALMP) creates doubts whether unemployment rate serves as an appropriate measure for labor market slack (Pannenberg and Schwarze 1998). Thus, the issue of existence of an East German wage curve forms a distinct focus of research (cf. Pannberg and Schwarze 1998; Baltagi, Blien and Wolf 2000; Elhorst, Blien and Wolf 2007).

Unemployment rates are measured at the level of both districts and employment agencies. The administrative districts are the smallest spatial units for which unemployment rates are reported. Because of their strong linkages to competencies and responsibilities in public employment administration (Hilbert 2008, pp. 73-74), employment agencies do not share the characteristics of functional regions (Kropp and Schwengler 2014). Although in most cases employment agencies consist of one

\footnotetext{
${ }^{2}$ In case of a negative spatial adjustment coefficient $\alpha^{*}$, above-equilibrium wages in the neighbouring regions would exert a downward pressure on local wages. In the scarce literature on the SpECM approach there is no consensus on the sign of the spatial error correction coefficient. While Beenstock and Felsenstein (2010) found the same sign for both adjustment coefficients in regional house price modelling, the findings of Mitze and Özyurt (2014) for trade- and FDI-driven productivity growth are completely in line with our reasoning.
} 
or more entire districts, different parts of administrative districts may be assigned to different agencies. Therefore, both unemployment rates and wages are collected at the level of NUTS-3 regions.

Official statistics provides different indicators for wages. The Regional Database Germany of the Federal Statistical Office reports gross wages and salaries per year. By dividing through the number of employees, yearly wages per worker are obtained. However, because the estimated wage curve elasticity can be affected by the cyclical behaviour of working hours, distortions may arise (Card 1995). To avoid this effect, we utilize hourly wages available from the Sample of Integrated Labour Market Biographies (SIAM) drawn from the Integrated Employment Biographies (IEB) of the Institute for Employment Research (IAB). The data relate to full-time employees subject to social security contributions with hourly wages of more than six Euro. Unemployment rates for NUTS-3 regions stem from the Labour Market Statistics of the German Federal Employment Agency (BA).

In investigating the impacts of economic conditions on wages, individual characteristics like vocational education, experience and gender for remuneration have to be included (cf. Heckman, Lochner and Todd 2003). In addition, working time, branch and firm size may influence hourly pay. Moreover, New Economic Geography (NEG) has brought market access into renewed prominence. Table 1 gives an overview of the control variables selected for this study and their potential relevance for wage determination.

Table 1 about here

The data requirements of the cointegration approach are checked on the basis of Pesaran's (2007) panel unit root test that accounts for cross-sectional dependence. While the test equation (5) is used with the intercept in testing for a unit root in the unemployment rate and the control variables, a linear trend is included as additional component for the wage.

Table 2 about here

Table 2 reports the results of the CIPS tests for the variables involved. By accounting for cross-sectional and serial dependence, the unit root hypothesis cannot be 
rejected for the wage and unemployment rate at any reasonable level of significance. As the CIPS test clearly rejects the null hypothesis of a unit root for the first differences of these variables, we conclude that these variables are integrated of order one. For the control variables, the unit root hypothesis is accepted for all but two cases at the 0.05 level of significance. At the 0.01 level, the null hypothesis cannot be rejected in any case. The first differenced series of all control variables are stationary and are included in the SpECM model. The CIPS test need not explicitly be performed for the spatial lagged variables, because they share the same integration properties as linear combinations of the original variables.

\section{Empirical Analysis}

As a first step, we examine, whether the variables are panel cointegrated in the sense that a linear combination between them becomes stationary. For this, different specifications of a potential long-run relationship between regional wage and unemployment rates are estimated. The estimation is performed for a non-spatial and spatial setting. Next, possible types of cointegration and short-run responses of wages to the explanatory variables are identified on the basis of the SpECM. Finally, a dynamic spatial wage curve for West Germany is obtained by combining the estimated long- and short-run models.

\subsection{Panel cointegration and long-run wage curve elasticities}

Econometric analysis of the relationship between the wage and unemployment rate starts with estimating and testing for a potential West German long-run wage curve leaving aside spatial effects. Table 3 displays the ML estimates of the FE model without and with instrumentation of the unemployment rate. In both cases the Hausman test clearly rejects random effects. Region and time fixed effects prove to be highly significant. For examining panel cointegration between the wage and unemployment rate along with control variables, the testing proceduce of Holly, Pesaran and Yamagata (2010) is employed. The null hypothesis of non-cointegration cannot be rejected when the residuals of the panel models are nonstationary. The HPY test accounts for cross-sectional dependence. If spillover effects from 
neighbouring areas only weak evidence for the existence of a West German long-run wage curve is obtained.

With a value of -0.0152 the wage curve elasticity is estimated nearly twice as large by instrumenting the unemployment rate compared to standard ML estimation of the FE model. Although the elasticity is low in relation to the empirical law of -0.1 (Blanchflower/Oswald 1994), it is precisely estimated with a coefficient/SE ratio of about $6.5 .^{3}$ In view of their high ratios between the response coefficients and their standard errors (SE), the shares of younger workers, high and low qualified workers, female workers, part-time workers, the share of the service sector and the size effect prove to be the most relevant controls in the marginally significant cointegration relationship.

Table 3 about here

Both spatial tests, Pesaran's local CD and the BSK test, point to the presence of spatial spillovers in wage determination. In this situation, the estimated unemployment elasticity of wages is known to be biased and inconsistent (cf. Anselin and Bera 1998, pp. 246-247). Therefore, information on goodness of fit, panel cointegration and regression coefficients of the Spatial Durbin panel model is provided (s. Table 4). Although the inclusion of spatially lagged variables does improve the overall fit only marginally, the test statistic of the HPY test now becomes highly significant. Thus, the evidence of a stable long-run relationship between wages and regional employment conditions is strengthened by accounting for spatial dependencies.

Table 4 about here

Considering spatial effects, the regression coefficient of own region's unemployment rate decreases irrespective of whether the unemployment rate is instrumented or not. In the non-spatial FE panel model spatial spillovers seem to be partly captured by the

\footnotetext{
${ }^{3}$ In panel data analysis, usually the Gauß test (z-test) is applied for assessing significance. This ignores the fact that estimated coefficients follow nonstandard distributions in the case of nonstationarity. Traditional significance tests on the regression coefficients in panel models used in established toolboxes and programs like Matlab, R, Stata and EViews should be interpreted with caution.

[Strictly speaking this implies that the critical value of $|1.96|$ for the $5 \%$ level of significance is abandoned. Under these circumstances usually larger coefficient/SE ratios are necessary to conclude significance.]
} 
local labour market conditions. An incorporation of economic conditions in neighbouring areas is strongly suggested by the comparatively large response coefficients of the spatially lagged unemployment rate. The coefficient/SE ratios between 2.5 and 3 indicate that the regression coefficients of both unemployment variables are relatively precisely estimated with the ML-IV approach. With a coefficient/SE ratio of about 10 the highest significance is obtained for the estimated spatially autoregressive parameter with a value of almost 0.2 .

The wage-unemployment relationship might be influenced by specific regional characteristics like experience, education, sectoral composition, firm size, urbanization and accessibility. According to the theoretical considerations not only own region's characteristics should matter but likewise those of proximate regions. From Table 4 it can be concluded that indeed both local and spatially lagged controls play an important role. The relevance of regional features in explaining the wage level occurs irrespectively of whether the unemployment rate is instrumented or not. In terms of coefficient/SE ratios the shares of old workers, qualified and unqualified workers, the shares of the service and agricultural sectors as well as firm size both in own and surrounding regions are most significant. In contrast, the effect on the share of part-time workers can be only established with respect to the larger labour market.

Table 5 about here

Due to the omission of endogenous feedback effects, the regression coefficients of the SDPM no longer render the marginal effects of the explanatory variables on the dependent variable. Lesage and Pace (2009, pp. 34-42) developed an impact analysis to identify direct and indirect effects. Direct impacts also capture circular routes of own region's impulses that pass through neighbouring areas before affecting the local wage level. Indirect impacts for a particular region are obtained by summing the marginal derivatives over all other regions. In view of the fact that the partial derivatives will vary from region to region, average direct, indirect and total impacts are utilized for assessing the variable-specific effects. The wage elasticities with respect to unemployment are presented in Table 5 for the ML and ML-IV estimates of the spatial Durbin panel model. The indirect impacts are additionally partitioned into first-order and higher-order effects. Impact analysis corroborates the 
greater indirect versus direct unemployment effects. Neglecting endogeneity of the unemployment even leads to lack of significance of the latter impact. With instrumentation the local unemployment elasticity of wages of -0.009 is highly significant, albeit lower in absolute value than the elasticity of -0.014 resulting from changes of the unemployment rate in neighbouring regions. The stronger indirect impact may be explained by monopsonistic competition relevant within travel-to-work areas, and thereby exceeding the boundaries of the districts. This interpretation is supported by the fact that higher order impacts play a negligible role. About 82 per cent of indirect effects is attributed to first-order neighbours.

\subsection{Spatial error-correction model and dynamic spatial wage curve}

The spatial error-correction model captures the effects of short-run changes in the log unemployment rate and regional characteristics along with those of local and neighbouring equilibrium deviations on the growth rate of wages. The lagged residuals are constituent parts of the error-correction mechanism operating within and between regions. The significantly negative error correction terms $\mathrm{EC}_{\mathrm{t}-\mathrm{1}}$ in Table 6 indicate the presence of local error correction and confirms the finding of the HPY cointegration test. With regard to the regional characteristics, about 40 percent of long-run imbalances from own region's equilibrium between unemployment and wages are corrected within a year. The significant error correction term W.EC $\mathrm{C}_{\mathrm{t}-1}$ signals that also a spatial error-correction mechanism is at force. 25 percent of neighbouring disequilibria spills over onto the own region after one year. Due to the effectiveness of both local and spatial error-correction, the system is said to be globally cointegrated.

Table 6 about here

From Table 6 it can be seen which variables induce short-run changes in the wage rate. Wage changes in the own region depend significantly on local wage variations in the previous period. The negative coefficient indicates that, viewed in isolation, prior increases of wages tend to decrease own region's wages. Just as in the longrun, spatial wage spillovers prove relevant in the short-run. Additionally, current changes of wages in neighbouring regions affect changes in local wages positively, whereas they are negatively correlated with spatially lagged wage differences of the 
previous period. Overall, however, positive wage spillovers can be established in the short-run.

In the short-run, contemporaneous variations in the unemployment rate significantly affect alterations in wages. While changes in the own region's labour market conditions exert a negative impact on local wage differences, the short-run influence from neighbouring regions is positive. No significant effects of lagged changes of unemployment rates in the own and proximate regions are established. Furthermore, Table 6 reveals that wage changes can be attributed in part to variations in regional characteristics. Both temporal differences of local and neighbouring characteristics will generate significant short-run effects on the adjustment of wages.

A cointegration-based dynamic spatial wage curve is derived by combining the equilibrium relationship and the spatial error correction model. For this, the error correction terms $\mathrm{EC}_{\mathrm{t}-1}$ and $\mathrm{W} \cdot \mathrm{EC}_{\mathrm{t}-1}$ are substituted by the estimated Spatial Durbin Panel Model (ML-IV). After some simplifications the dynamic wage-unemployment relationship

(8) $\log \left(w_{r t}\right)=0.5243 \cdot \log \left(w_{r, t-1}\right)+0.0679 \cdot \log \left(w_{r, t-2}\right)+0.4669 \cdot\left(\sum_{s=1}^{n} w_{r s} \cdot \log \left(w_{s t}\right)\right)$

$-0.2821 \cdot\left(\sum_{s=1}^{n} w_{r s} \cdot \log \left(w_{s, t-1}\right)\right)+0.1448 \cdot\left(\sum_{s=1}^{n} w_{r s} \cdot \log \left(w_{s, t-2}\right)\right)-0.0118 \cdot \log \left(u_{t}\right)$

$+0.0019 \cdot \log \left(u_{r, t-1}\right)+0.0061 \cdot \log \left(u_{r, t-2}\right)+0.0157 \cdot\left(\sum_{s=1}^{n} w_{r s} \cdot \log \left(u_{s t}\right)\right)$

$-0.0109 \cdot\left(\sum_{s=1}^{n} w_{r s} \cdot \log \left(u_{s, t-1}\right)\right)-0.0066 \cdot\left(\sum_{s=1}^{n} w_{r s} \cdot \log \left(u_{s, t-2}\right)\right)+C_{r t}+C_{r, t-1}+C_{r, t-2}$

is obtained that is similarly structured to its standard representation. The terms $\mathrm{C}_{\mathrm{rt}}$, $\mathrm{C}_{\mathrm{r}, \mathrm{t}-1}$ and $\mathrm{C}_{\mathrm{r}, \mathrm{t}-2}$ capture the contemporaneous and lagged effects of the control variables and lagged second-order wage and unemployment spillovers.

As the estimated coefficient of 0.524 of lagged wages is significantly different from 1 , the Phillips curve hypothesis is clearly rejected. At the same time, the autoregressive coefficient deviates significantly from 0 . The finding of substantial inertia in the adjustment of wages to the long-run equilibrium relationship is well in line with the evidence from the dynamic spatial panel approach of Baltagi, Blien and Wolf (2012). 
Qualitatively this also complies with the ECM results of Ammermüller et al. (2010). The larger estimated autoregressive parameter from the non-spatial ECM reparameterization is partly due to the missing second-order lag. Spatial autocorrelation of wages is additionally identified by significant coefficients of contemporaneous and past spatially lagged wages.

Present and past labour market conditions are also relevant for local wages. The own region's employment situation is reflected in the wage rate without measurable delay. This is somewhat in variance with findings by Ammermüller et al. (2010) of similar regression for the present and previous unemployment rate. Negative effects of high unemployment in proximate regions seem to prevail only after two to three periods. While spatial unemployment spillovers are positive in the short-run, the overall spatially lagged unemployment impact on wages is negative.

\section{Conclusions}

By adopting a global cointegration approach to wage curve analysis, the risk of spurious regression with nonstationary variables is adequately addressed in a spatial panel setting. In accounting for cross-sectional dependence, the CIPS test disclosed non-stationarity of panel variables forming the wage-unemployment nexus. The panel cointegration test of Holly, Pesaran and Yamagata (2010) gives evidence for the existence of a long-run wage curve for West Germany. In conjunction with territorial characteristics, regional wage and unemployment rates prove to be locally and spatially cointegrated. The inclusion of spatial effects substantially strengthens the cointegrating relationship. When spatial effects are neglected, the cointegration vector is only marginally significant.

In a spatial setting with endogenous spatial spillovers, the regression coefficients do not reflect the marginal effects of the explanatory variables on the dependent variable. Here estimates of unemployment elasticities of pay are derived from impact analysis (Laplace and Pace 2009, pp. 34-42). In accordance with Ammermüller et al. (2010) and Baltagi, Blien and Wolf (2012) the estimated wage curve elasticities lie well below Blanchflower and Oswald's (1995) popularized average value of -0.1. Both the direct and indirect effect prove to be significant with the latter even slightly greater 
than the former. More than $80 \%$ of unemployment spillovers result from first-order neighbours. The high relevance of surrounding regions gives support to the theory of monopsonistic competition. The total impact of regional unemployment on the wage amounts to almost -0.025 .

Global cointegration between wage and unemployment rates in the presence of regional characteristics is inferred as well from the spatial error correction model as the dynamic counterpart to the cointegrating relationship. Both the local and spatial error correction mechanism prove to be effective in establishing the long-run equilibrium. Significant short-run effects stem from lagged changes in wage rates and current and lagged changes in unemployment rates in the own and surrounding regions. This also holds for most regional characteristics. On the basis of the dynamic specification of the wage curve, the Phillips curve hypothesis is clearly rejected for the West German economy.

Future research on the global cointegration approach to wage curve analysis may offer closer insight into heterogeneity with respect to different groups of workers and types of regions. In this study, group effects in determination of regional wages are reflected by different influences of regional characteristics like the shares of female, qualified, unqualified, young and part-time workers. Strong impacts are also observed for sector type and spatial category. Monopsonistic competition may vary substantially between these worker groups and region types. With regard to equilibrium adjustment, heterogeneity of error correction mechanisms may be revealed. 


\section{References}

Ammermüller, A., Lucifora, C., Origo, F., Zwick, T. (2012), Wage Flexibility in Regional Labour Markets: Evidence from Italy and Germany, Regional Studies 44, 401-421.

Anselin and Bera (1998), Spatial Dependence in Linear Regressions Models with an Introduction to Spatial Econometrics, in: Ullah, A. and Giles, D.E.A, (eds.), Handbook of Applied Economic Statistics. Marcel Decker, New York, NY, Basel, Switzerland, 237-289.

Baltagi, B.H., Blien U. and Wolf, K. (2000), The East German Wage Curve: Evidence from the IAB Employment Sample, Economic Letters 61, 135-142.

Baltagi, B.H., Blien, U., Wolf, K. (2009): "New evidence on the dynamic wage curve for Western Germany: 1980-2004", Labour Economics, 16 (1), pp. 47-51.

Baltagi, B.H., Blien, U., Wolf, K. (2012): "A dynamic spatial panel data approach to the German wage curve", Economic Modelling, 29 (1), pp. 12-21.

Baltagi, B.H., Song, S.H. and Koh, W. (2003) Testing panel data regression models with spatial error correlation. Journal of Econometrics, 117, 123-150.

Bande, R., Fernández, M., Montuenga, V. (2012), Wage flexibility and local labour markets: a test on the homogeneity of the wage curve in Spain, Investigaciones Regionales 24, 175-198.

Blanchard, O., Wolfers, J, (2000), The Role of Shocks and Institutions in the Rise of European Unemployment: The Aggregate Evidence, Economic Journal 110, C1-C33.

Blanchflower, D. G., Oswald, A. J. (1990): "The wage curve", Scandinavian Journal of Economics, 92 (2), pp. 215-235.

Blanchflower, D. G., Oswald, A. J. (1994a): "Estimating a wage curve for Britain 1973-1990", The Economic Journal, 104 (426), pp. 1025-1043.

Blanchflower, D. G., Oswald, A. J. (1994b), The wage curve, MIT Press, Cambridge and London.

Blanchflower, D. G., Oswald, A. J. (1995), An Introduction to the Wage Curve, Journal of Economic Perspectives 9, 153-167.

Blanchflower, D. G., Oswald, A. J. (2005): The Wage Curve Reloaded, NBER Working Paper No. 11338

Campbell, C., Orszag, J.M. (1998), A Model of the Wage Curve, Economic Letters 59, 119-125.

Card, D. (1995), The Wage Curve: A Review, Journal of Economic Literature 33, 785-799. 
Choi, I. (2015), Panel Cointegration, in: Baltagi, B.H. (ed.), Oxford Handbook of Panel Data Econometrics, Oxford University Press, New York, N.Y., 46-75.

Daouli, J., Demoussis, M., Giannakopoulos, N. Laliotis, I. (2015), The wage curve in Greece: 1999-2013, Discussion Paper, Department of Economics, University of Patras, Greece.

Elhorst J.P (2010), Spatial Panel Data Models, in: Fischer, M.M., Getis A. (eds.), Handbook of Applied Spatial Analysis. Springer-Verlag, , Berlin, Heidelberg, Germany, 377-407.

Elhorst, J. P., Blien, U. and Wolf, K. (2007), New evidence on the wage curve: A spatial panel approach, International Regional Science Review 30, 173-191.

Fingleton, B., Palombi, S. (2013), The Wage Curve Reconsidered: Is it Truly an 'Empirical Law of Economics'?, Région et développement 38, 49-92.

Fitzenberger, B., Kohn, K., Lembcke, A. (2013), Union Density and Varieties of Coverage: The Anatomy of Union Wage Effects in Germany. Industrial and Labor Relations Review 66, 169-197.

García-Mainar, I., Montuenga-Gómez,V.M. (2012); Wage dynamics in Spain: evidence from individual data (1994-2001 Investigaciones Regionales 24, 41-56:

Gertler, P. (2010), The Wage Curve: A Panel Data View of Labour Market Segments, National Bank of Slovakia, Working Paper No. 3-201, Bratislava, Slovakia.

Harris, J., Todaro, M. (1970): "Migration, Unemployment and Development: A TwoSector Analysis", American Economic Review, 60, pp. 126-142.

Heckman, J.J., Lochner L.J., Todd, P.E. (2003), Fifty Years of Mincer Earnings Regressions, Technical Report 9732, National Bureau of Economic Research (NBER), Cambridge, MA.

Hilbert, c. (2008), Unemployment, Wages, and the Impact of Active Labour Market Policies in a Regional Perspective, Logos, Berlin.

Holly, S., Pesaran, M.H., Yamagata, T. (2010), A spatio-temporal model of house prices in the USA, Journal of Econometrics 158, 160-173.

Kropp, P., Schwengler, B. (2014), Three-step method for delineating functional labour market regions, Regional Studies, published online.

LeSage, J. and Pace, R.K. (2009), Introduction to Spatial Econometrics, Chapman \& Hall/CRC, Boca Raton, FL.

Longhi S., Nijkamp P., Poot J. (2006), Spatial Heterogeneity and the Wage Curve Revisited, Journal of Regional Science 46, 707-731. 
Mitze, T., Özyurt, S. (2014), The Spatial Dimension of Trade- and FDI-driven Productivity Growth in Chinese Provinces: A Global Cointegration Approach, Growth and Change 45, 263-291.

Moulton, B.R. (1990), An Illustration of a Pitfall in Estimating the Effects of Aggregate Variables on Micro Units, Review of Economics and Statistics 72, 334-338.

Nijkamp, P., Poot, J. (2005): The Last Word on the Wage Curve? A Meta-Analytic Assessment, Journal of Economic Surveys, 19 (3), pp. 421-450.

Pannenberg, M., Schwarze, J. (1998), Labor market slack and the wage curve, Economics Letters 58, 351-354.

Pannenberg, M., Schwarze, J. (2000), Wage Dynamics and Unemployment in Germany: Evidence from Regional Panel Data, Labour 14, 645-655.

Pesaran, M.H. (2004). General Diagnostic Tests for Cross Section Dependence in Panels, CESifo Working Paper Series No. 1233, 255-260.

Pesaran, M.H. (2007), A Simple Panel Unit Root Test in the Presence of CrossSection Dependence, Journal of Applied Econometrics 22, 265-312.

Piras, G. (2013), Impact Estimates for Static Spatial Panel Data Models in R, Regional Research Institute, Working Paper Number 2013-05, West Virginia University, Morgantown, WV.

Ramos, A., Nicodemo, C., Sanmorá, E. (2014), A spatial panel wage curve for Spain, Letters in Spatial and Resource Sciences 8, 125-139.

Seifert, H., Massa-Wirth, H. (2005), Pacts for employment and competitiveness in Germany, Industrial Relations Journal 36, 217-240.

Shapiro, C., Stiglitz, J.E. (1984), Equilibrium Unemployment as a Worker Discipline Device, American Economic Review 74, 433-444.

Topel, R.H. (1986), Local labor markets, Journal of Political Economy 94, Supplement, 111-143. 
Table 1: Regional characteristics

\begin{tabular}{|c|c|c|c|}
\hline Type of control & Variable & Indicator & Relevance \\
\hline Experience & $\begin{array}{l}\text { Share of youn- } \\
\text { ger workers } \\
\text { Share of elder } \\
\text { workers }\end{array}$ & $\begin{array}{l}\text { Share of employ- } \\
\text { yees younger } \\
\text { than } 30 \text { years } \\
\text { Share of employ- } \\
\text { yees of } 50 \text { years } \\
\text { or older }\end{array}$ & $\begin{array}{l}\text { Less work experience; } \\
\text { cognitive abilities } \\
\text { (speed and memory) } \\
\text { More work experience; } \\
\text { less physical strength; } \\
\text { cognitive abilities (vo- } \\
\text { cabulary size, verbal } \\
\text { abilities) }\end{array}$ \\
\hline $\begin{array}{l}\text { Vocational } \\
\text { education }\end{array}$ & $\begin{array}{l}\text { Share of high } \\
\text { qualified } \\
\text { workers } \\
\text { Share of low } \\
\text { qualified wor- } \\
\text { kers }\end{array}$ & $\begin{array}{l}\text { Share of emplo- } \\
\text { yees with an } \\
\text { acad. degree } \\
\text { Share of employ- } \\
\text { yees without vo- } \\
\text { cational training } \\
\text { qualification }\end{array}$ & $\begin{array}{l}\text { Benefits of higher edu- } \\
\text { cation („education } \\
\text { pays") } \\
\text { Low-productivity wor- } \\
\text { kers }\end{array}$ \\
\hline Gender & $\begin{array}{l}\text { Share of fe- } \\
\text { male workers }\end{array}$ & $\begin{array}{l}\text { Share of female } \\
\text { workers }\end{array}$ & $\begin{array}{l}\text { Higher labour supply } \\
\text { elasticity; less em- } \\
\text { ployed in sectors with } \\
\text { high entry/exit costs }\end{array}$ \\
\hline Working time & $\begin{array}{l}\text { Share of part- } \\
\text { time workers }\end{array}$ & $\begin{array}{l}\text { Share of part- } \\
\text { time workers }\end{array}$ & $\begin{array}{l}\text { Less bargaining power } \\
\text { (high share in unfa- } \\
\text { vourable business } \\
\text { conditions) }\end{array}$ \\
\hline Firm size & Firm size & $\begin{array}{l}\text { Average number } \\
\text { of employees per } \\
\text { firm in full-time } \\
\text { equivalents }\end{array}$ & $\begin{array}{l}\text { Small firms have lower } \\
\text { monitoring costs and } \\
\text { offer different } \\
\text { employment } \\
\text { opportunities than } \\
\text { large firms }\end{array}$ \\
\hline \multirow[t]{2}{*}{$\begin{array}{l}\text { Sectoral } \\
\text { composition }\end{array}$} & Service sector & $\begin{array}{l}\text { Share of em- } \\
\text { ployees in ser- } \\
\text { vice sector }\end{array}$ & $\begin{array}{l}\text { Sectoral wage diffe- } \\
\text { rentials }\end{array}$ \\
\hline & $\begin{array}{l}\text { Agricultural } \\
\text { sector }\end{array}$ & $\begin{array}{l}\text { Share of em- } \\
\text { ployees in agri- } \\
\text { culture sector }\end{array}$ & Low-wage sector \\
\hline $\begin{array}{l}\text { Centres and } \\
\text { accessibiilty }\end{array}$ & $\begin{array}{l}\text { Urbanization } \\
\text { (Agglome- } \\
\text { ration) }\end{array}$ & $\begin{array}{l}\text { Share of agricul- } \\
\text { ture in own re- } \\
\text { gion and sur- } \\
\text { roundings }\end{array}$ & $\begin{array}{l}\text { Higher wages in urba- } \\
\text { nized regions due to } \\
\text { agglomeration advan- } \\
\text { tages }\end{array}$ \\
\hline
\end{tabular}


Table 2: Cross-sectionally augmented IPS test (CIPS test)

\begin{tabular}{|c|c|c|c|c|}
\hline & Level & $p$-value & Difference & $p$-value \\
\hline Log wage rate & -2.4691 & 0.116 & -2.8932 & 0.000 \\
\hline Log unemployment rate & -1.2573 & 0.999 & -2.4720 & 0.000 \\
\hline Share of younger workers & -2.064 & 0.056 & -2.5297 & 0.000 \\
\hline Share of elder workers & -2.0113 & 0.068 & -2.3353 & 0.000 \\
\hline $\begin{array}{l}\text { Share of high qualified } \\
\text { workers }\end{array}$ & -1.9039 & 0.871 & -2.2489 & 0.000 \\
\hline $\begin{array}{l}\text { Share of low qualified } \\
\text { workers }\end{array}$ & -2.1209 & 0.013 & -2.4398 & 0.000 \\
\hline Share of female workers & -2.0408 & 0.047 & -2.3876 & 0.000 \\
\hline Share of part-time workers & -1.8416 & 0.277 & -2.2158 & 0.000 \\
\hline Share of agricultural sector & -1.5990 & 0.691 & -2.3177 & 0.000 \\
\hline Share of service sector & -1.7794 & 0.375 & -2.2517 & 0.000 \\
\hline $\begin{array}{l}\text { Average size of enter- } \\
\text { prises }\end{array}$ & -1.6006 & 0.688 & -2.2354 & 0.000 \\
\hline $\begin{array}{l}\text { Square average size of } \\
\text { enterprises }\end{array}$ & -1.6554 & 0.589 & -2.2305 & 0.000 \\
\hline
\end{tabular}

Note: Panel unit root test of Pesaran (2007) allowing for cross-sectional dependence by adopting a common factor model. In the test equation (5) of the CIPS test, the common factor is proxied by the cross-section means of the dependent variable. The unit root hypothesis for all regions $\left(\mathrm{H}_{0}\right)$ is tested against the hypothesis that some time series are stationary $\left(\mathrm{H}_{1}\right)$. For the level of the log wage rate, a deterministic trend is included. 
Table 3: Nonspatial FE models of the wage curve

\begin{tabular}{|c|c|c|c|c|}
\hline & \multicolumn{2}{|c|}{ Nonspatial FE Model (ML) } & \multicolumn{2}{|c|}{ Nonspatial FE Model (ML-IV) } \\
\hline & Coefficients & Stand. Errors & Coefficients & Stand. Errors \\
\hline $\log (u)$ & $-0.0082^{\star \star}$ & 0.0026 & $-0.0152^{\star \star}$ & 0.0033 \\
\hline young & $0.1799 * *$ & 0.0361 & $0.1775^{\star \star}$ & 0.0361 \\
\hline old & -0.0073 & 0.0268 & -0.0077 & 0.0268 \\
\hline qual & $1.3372^{\star \star}$ & 0.0528 & $1.3463^{\star *}$ & 0.0529 \\
\hline unqual & $-0.1350 * \star$ & 0.0324 & $-0.1185^{\star \star}$ & 0.0328 \\
\hline female & $0.0742^{\star}$ & 0.0324 & $0.0793^{\star}$ & 0.0325 \\
\hline part-time & $-0.0924^{\star}$ & 0.0369 & $-0.0958 * \star$ & 0.0370 \\
\hline service & $-0.1923^{\star \star}$ & 0.0175 & $-0.1868^{\star \star}$ & 0.0176 \\
\hline agrar & -0.1493 & 0.1295 & -0.1432 & 0.1297 \\
\hline size & $0.0155^{\star *}$ & 0.0015 & $0.0152^{\star *}$ & 0.0015 \\
\hline$(\text { size })^{2}$ & $-0.00028^{\star \star}$ & 0.00003 & $-0.00028^{\star \star}$ & 0.00003 \\
\hline & FE & $\begin{array}{l}\text { - Regions } \\
\text { - Time }\end{array}$ & FE & $\begin{array}{l}\text { - Regions } \\
\text { - Time }\end{array}$ \\
\hline & Pseudo $\mathrm{R}^{2}$ & 0.9830 & Pseudo $\mathrm{R}^{2}$ & 0.9830 \\
\hline & $\mathrm{F}$ & $117.337^{\star \star}$ & $\mathrm{F}$ & $116.505^{\star \star}$ \\
\hline & Hausman & $4703.671^{\star *}$ & Hausman & $3119.098 * *$ \\
\hline & BSK & $12.194^{* \star}$ & BSK & $12.088^{* *}$ \\
\hline & Local CD & $10.198 * \star$ & Local CD & $9.873^{\star \star}$ \\
\hline & HPY coint. test & $-2.0181^{(\star)}$ & HPY coint. test & $-2.0189^{(*)}$ \\
\hline
\end{tabular}

Notes: ${ }^{* *},{ }^{*}{ }^{(*)}$ denote significance at the 1,5 , and $10 \%$ level, respectively. Pseudo $\mathrm{R}^{2}$ is the squared correlation between the observed and predicted dependent variable. $F$ indicates the $F$ test for the overall fit of the model. The Hausman test compares the random effects model $\left(\mathrm{H}_{0}\right)$ against the fixed effects model $\left(\mathrm{H}_{1}\right)$. BSK is the Baltagi, Song and Koh (2003) for spatial error correlation. Local CD is the local variant of Pesaran's (2004) CD test for cross-sectional dependence. HPY stands for the panel cointegration tests of Holly, Pesaran and Yamagata (2010). 
Table 4: Spatial Durbin panel model (SDPM) of the wage curve

\begin{tabular}{|c|c|c|c|c|}
\hline & \multicolumn{2}{|c|}{ Spatial FE Lag Model (ML) } & \multicolumn{2}{|c|}{ Spatial FE Lag Model (ML-IV) } \\
\hline & Coefficients & Stand. Errors & Coefficients & Stand. Errors \\
\hline $\log (u)$ & $-0.0055^{(*)}$ & 0.0031 & $-0.0085^{\star \star}$ & 0.0028 \\
\hline$W \log (\mathrm{u})$ & $-0.0101^{\star}$ & 0.0043 & $-0.0097^{*}$ & 0.0039 \\
\hline W log(w) & $0.1888^{\star \star}$ & 0.0193 & $0.1852^{\star \star}$ & 0.0194 \\
\hline young & 0.0274 & 0.0344 & 0.0259 & 0.0344 \\
\hline old & $-0.0504^{*}$ & 0.0251 & $-0.0507^{*}$ & 0.0251 \\
\hline qual & $1.2954^{\star \star}$ & 0.0516 & $1.2874^{\star \star}$ & 0.0515 \\
\hline unqual & $-0.1102^{\star \star}$ & 0.0305 & $-0.1026^{\star \star}$ & 0.0306 \\
\hline female & $-0.0616^{(*)}$ & 0.0365 & -0.0582 & 0.0365 \\
\hline part-time & 0.0072 & 0.0389 & 0.0111 & 0.0388 \\
\hline service & $-0.2102^{\star \star}$ & 0.0163 & $-0.2082^{\star \star}$ & 0.0163 \\
\hline agrar & -0.1907 & 0.1203 & $-0.2060^{(*)}$ & 0.1201 \\
\hline size & $0.0116 * \star$ & 0.0014 & $0.0114^{\star \star}$ & 0.0014 \\
\hline$(\text { size })^{2}$ & $-0.000215^{\star \star}$ & 0.000034 & $-0.000214^{\star \star}$ & 0.000034 \\
\hline W young & $0.6716^{\star \star}$ & 0.0645 & $0.6738^{\star \star}$ & 0.0644 \\
\hline W old & $0.1212^{\star \star}$ & 0.0399 & $0.1106^{\star \star}$ & 0.0397 \\
\hline W qual & $-0.5257^{\star \star}$ & 0.1016 & $-0.5558^{\star \star}$ & 0.1013 \\
\hline W unqual & $-0.3243^{\star \star}$ & 0.0531 & $-0.3236^{\star \star}$ & 0.0530 \\
\hline W female & 0.0092 & 0.0569 & 0.0036 & 0.0568 \\
\hline W part-time & $-0.2733^{\star \star}$ & 0.0745 & $-0.2646^{\star \star}$ & 0.0744 \\
\hline W service & $0.2274^{\star \star}$ & 0.0314 & $0.2300^{\star *}$ & 0.0313 \\
\hline W agrar & $-0.4066^{*}$ & 0.1917 & $-0.4116^{*}$ & 0.1913 \\
\hline W.size & $0.0246 \star \star$ & 0.0062 & $0.0237^{\star \star}$ & 0.0062 \\
\hline \multirow[t]{5}{*}{$W \cdot(\text { size })^{2}$} & $-0.0011^{\star *}$ & 0.0002 & $-0.0010^{\star *}$ & 0.0002 \\
\hline & FE & regions, time & FE & regions, time \\
\hline & SER & 0.0156 & SER & 0.0147 \\
\hline & Pseudo-R ${ }^{2}$ & 0.9846 & Pseudo- $R^{2}$ & 0.9846 \\
\hline & HPY coint. test & $-2.5467^{* *}$ & HPY coint. test & $-2.7193^{\star *}$ \\
\hline
\end{tabular}

Notes: ${ }^{* *},{ }^{*},{ }^{(*)}$ denote significance at the 1,5 , and $10 \%$ level, respectively. $\mathrm{W}$ indicates the spatial lag of a variable. SER is the standard error of regression. Pseudo $\mathrm{R}^{2}$ is the squared correlation between the observed and predicted dependent variable. HPY stands for the panel cointegration tests of Holly, Pesaran and Yamagata (2010). 
Table 5: Average direct, indirect and total unemployment impacts on wages

\begin{tabular}{|c|c|c|}
\hline & $\begin{array}{l}\text { Spatial Durbin Panel Model } \\
(\mathrm{ML})\end{array}$ & $\begin{array}{l}\text { Spatial Durbin Panel Model } \\
\text { (ML-IV) }\end{array}$ \\
\hline Direct impact & -0.00018 & $-0.00852^{\star \star}$ \\
\hline Indirect impact & $-0.02408^{* *}$ & $-0.01379 *$ \\
\hline - First-order impact & $-0.02004^{* *}$ & $-0.01132^{*}$ \\
\hline - Higher order impacts & $-0.00404 * *$ & $-0.00247 *$ \\
\hline Total impact & $-0.02426^{\star *}$ & $-0.02231^{*}$ \\
\hline $\begin{array}{l}\text { - Direct and first-order } \\
\text { impact }\end{array}$ & $-0.02022^{\star *}$ & $-0.01984^{\star}$ \\
\hline
\end{tabular}


Table 6: Spatial error correction model (SpECM)

\begin{tabular}{|c|c|c|c|c|}
\hline & \multicolumn{2}{|c|}{ SpECM } & \multicolumn{2}{|c|}{ SpECM IV } \\
\hline & Coefficients & Stand. Errors & Coefficients & Stand. Errors \\
\hline Intercept & $0.0069^{*}$ & 0.0029 & $0.0070^{*}$ & 0.0029 \\
\hline$\Delta \log \left(w_{t-1}\right)$ & $-0.0670^{\star \star}$ & 0.0143 & $-0.0679 \star \star$ & 0.0143 \\
\hline$\Delta W \log \left(w_{t}\right)$ & $0.4651^{\star *}$ & 0.0219 & $0.4669 * \star$ & 0.0219 \\
\hline$\Delta \mathrm{W} \log \left(\mathrm{W}_{\mathrm{t}-1}\right)$ & $-0.1470^{* *}$ & 0.0169 & $-0.1448^{\star *}$ & 0.0169 \\
\hline$\Delta \log \left(u_{t}\right)$ & -0.0023 & 0.0039 & $-0.0118^{\star}$ & 0.0057 \\
\hline$\Delta \log \left(\mathrm{u}_{\mathrm{t}-1}\right)$ & -0.0049 & 0.0040 & -0.0061 & 0.0040 \\
\hline$\Delta W \log \left(u_{t}\right)$ & 0.0057 & 0.0043 & $0.0157^{*}$ & 0.0062 \\
\hline$\Delta \mathrm{W} \log \left(\mathrm{u}_{\mathrm{t}-1}\right)$ & 0.0060 & 0.0045 & 0.0066 & 0.0045 \\
\hline$E C_{t-1}$ & $-0.4078^{\star *}$ & 0.0141 & $-0.4078^{\star *}$ & 0.0141 \\
\hline$W E C_{t-1}$ & $0.2509 \star \star$ & 0.0253 & $0.2541^{\star \star}$ & 0.0253 \\
\hline$\Delta$ young $_{\mathrm{t}-1}$ & $-0.2353^{* *}$ & 0.0539 & $-0.2283^{* *}$ & 0.0540 \\
\hline$\Delta$ qual $_{\mathrm{t}}$ & $0.1754^{\star}$ & 0.0890 & $0.1716^{\star}$ & 0.0889 \\
\hline$\Delta$ quall $_{\mathrm{t}-1}$ & $0.5959 * \star$ & 0.0899 & $0.5954^{\star *}$ & 0.0899 \\
\hline$\Delta$ unqual $_{\mathrm{t}}$ & $-0.1148^{\star}$ & 0.0480 & $-0.1128^{*}$ & 0.0480 \\
\hline$\Delta$ female $_{\mathrm{t}-1}$ & $-0.1005^{*}$ & 0.0440 & $-0.0949 *$ & 0.0441 \\
\hline$\Delta$ part-time $_{\mathrm{t}-1}$ & $0.2926^{\star *}$ & 0.0495 & $0.2896^{\star *}$ & 0.0495 \\
\hline$\Delta$ service $_{\mathrm{t}}$ & $-0.0883^{\star *}$ & 0.0189 & $-0.0872^{\star \star}$ & 0.0189 \\
\hline$\Delta$ service $_{\mathrm{t}-1}$ & $-0.0416^{\star}$ & 0.0191 & $-0.0416^{\star}$ & 0.0191 \\
\hline$\Delta$ agrar $_{\mathrm{t}-1}$ & $-0.6290^{* *}$ & 0.1518 & $-0.6397^{\star *}$ & 0.1522 \\
\hline$\Delta$ size $_{\mathrm{t}}$ & $0.0061^{\star *}$ & 0.0018 & $0.0060^{\star *}$ & 0.0018 \\
\hline$\Delta\left(\text { size }_{t}\right)^{2}$ & $-0.000075^{(*)}$ & 0.00004 & $-0.000073^{(*)}$ & 0.000040 \\
\hline$\Delta$ size $_{\mathrm{t}-1}$ & $-0.0055^{\star \star}$ & 0.0018 & $-0.0053^{\star \star}$ & 0.0018 \\
\hline$\Delta \mathrm{W}$ young $\mathrm{t}_{\mathrm{t}}$ & $0.2467^{\star \star}$ & 0.0881 & $0.2376^{\star \star}$ & 0.0877 \\
\hline$\Delta \mathrm{W}_{\text {young }}-1$ & $-0.5236^{\star *}$ & 0.0880 & -0.5259 ** & 0.0881 \\
\hline$\Delta \mathrm{W}_{\text {qual }}$ & $0.3250^{\star}$ & 0.1649 & $0.3384^{\star}$ & 0.1651 \\
\hline$\Delta \mathrm{W}$ unqual $_{\mathrm{t}}$ & $-0.1726^{*}$ & 0.0880 & $-0.1842^{*}$ & 0.08770 \\
\hline$\Delta \mathrm{W}$ unqual $\mathrm{I}_{\mathrm{t}-1}$ & $0.1631^{(*)}$ & 0.0853 & $0.1563^{(*)}$ & 0.0854 \\
\hline$\Delta \mathrm{W}$ female $_{\mathrm{t}}$ & $-0.1920^{\star \star}$ & 0.0578 & $-0.2008^{\star \star}$ & 0.0578 \\
\hline$\Delta \mathrm{W}_{\text {part-time }}$ & $-0.1947^{\star}$ & 0.0826 & $-0.1877^{\star}$ & 0.0821 \\
\hline$\Delta \mathrm{W}$ service $_{\mathrm{t}}$ & $0.0824^{*}$ & 0.0339 & $0.0751^{*}$ & 0.0344 \\
\hline$\Delta \mathrm{W}$ agrar $_{\mathrm{t}-1}$ & $-0.6749 * *$ & 0.2023 & $0.6256^{\star *}$ & 0.2038 \\
\hline & SER & 0.0121 & SER & 0.0121 \\
\hline & $\mathrm{R}^{2}$ & 0.667 & $\mathrm{R}^{2}$ & 0.667 \\
\hline & $\mathrm{F}$ & $183.8^{\star *}$ & $\mathrm{~F}$ & $184.1^{* \star}$ \\
\hline
\end{tabular}

Notes: ${ }^{* *},{ }^{*}{ }^{(*)}$ denote significance at the 1,5 , and $10 \%$ level, respectively. $\mathrm{EC}_{\mathrm{t}-1}$ is the local error correction term and $\mathrm{W} \mathrm{EC}_{\mathrm{t}-1}$ the spatial error correction term. $\mathrm{W}$ indictes the spatial lag of a variable. SER is the standard error of regression. $\mathrm{R}^{2}$ is the determination coefficient. $\mathrm{F}$ indicates the $\mathrm{F}$ test for the overall fit of the model. 